\title{
The Impact of Capital Subsidy Incentive on Renewable Energy Deployment in Long-Term Power Generation Expansion Planning
}

\author{
Mustafa Ozcan ${ }^{1}$, Mehmet Yildirim² \\ ${ }^{1}$ Corresponding Author; Electricity and Electronics Department, Şişli Technical School, Şişli, 34381, İstanbul, \\ Turkey; ozcanm2000@gmail.com, +90 5354144527 \\ ${ }^{2}$ Information Systems Engineering Department, Kocaeli University, Umuttepe, 41380, Kocaeli, Turkey
}

Received 08 October 2018; Accepted 31 October 2018; Published online 18 December 2018

\begin{abstract}
Capital investment cost is the major obstacle to the increasing share of electricity from renewable energy sources (RES-E). Therefore, RES-E incentive mechanisms are incorporated into markets to compensate cost-related barriers and to increase RES-E deployment rate. In this study, the impact of direct capital investment subsidy on RES-E in generation expansion planning (GEP) has been analyzed and deployment rates of renewable power plants have been defined. The effect of current subsidy mechanisms on the installed power capacity of various sources has also been analyzed and policy recommendations have been put forth in the light of the characteristics of Turkey's current subsidization mechanism and its outcomes.

Genetic algorithm was applied to solve the GEP problem. The share of non-hydro renewable power plants for future additions in overall installed power was determined as $9.45 \%$ without the proposed incentive, while it was estimated to rise to $13.65 \%$ when it was promoted by direct capital investment subsidy of $50 \%$. The deployment rates of renewable power plants are expected to grow as the imported coal share in total installed power is expected to decline after applying the proposed subsidy.
\end{abstract}

Key Words: Renewable energy, Generation expansion planning, Incentives, Capital subsidy, Genetic algorithm.

\section{Introduction}

Introducing renewable power plants as candidate plants in power generation expansion planning (GEP) will help diminish supply deficiency, decrease foreign energy dependency and reduce greenhouse gas (GHG) emissions.

Turkey has been experiencing rapid energy demand growth over the last decade, consequently the country's dependency on energy imports has increased [1, 2]. Approximately 75\% of Turkey's total primary energy supply (TPES) is imported and the country is heavily reliant on imported natural gas and oil.

The country's total net electricity generation increased from 23.275 TWh in 1980 to 250.436 TWh in 2014 [3, 4]. In 2017, Turkey's electricity generation was 295.500 TWh [5] while the gross domestic product (GDP) increased from 67.46 billions of dollars to 800.11 billions of dollars within the same time period [6]. When Turkey's total net electricity consumption between 1980-2014 is analyzed, it can be seen that there has been a steady increase in consumption, except the limited decrease in the aftermath of the economic crises $[4,7,8]$. The total net electricity consumption was $554 \mathrm{kWh}$ per capita in 1980, which increased to 3,288 kWh per capita in 2014 [4, 8, 9, 10].

Hydroelectric power plants (HPP) account for the largest share of Turkey's total installed power and are dominant among renewable power plants. However, most of Turkey's electricity generation is based on fossil-fuel power plants and natural gas is the dominant one. The share of fossilfuels in electricity generation increased from 51\% in 1980 to $79 \%$ in 2014 [3, 4]. In 2017, the share of fossilfuels in electricity generation was $71 \%$ [5].

Carbon dioxide $\left(\mathrm{CO}_{2}\right)$ emission has the largest share among the anthropogenic GHG emissions, which are the leading cause of global warming. Even though Turkey's $\mathrm{CO}_{2}$ emission per capita is below the world average, there is a rather high surge in emissions $[11,12,13,14]$. Total GHG emissions in Turkey 
increased by $125 \%$ since 1990, and the amount reached $467.6 \mathrm{Mt} \mathrm{CO}_{2}$-eqv. in 2014. Energy-related emissions are the largest source of GHG emissions in Turkey, accounting for $72.5 \%$ of the total [14].

Coal is still the backbone of Turkish energy sector [2] and 33\% of GHG emissions is caused by the coal combustion. Despite this issue, Turkey aims to utilize all existing domestic lignite and hard coal potential for power generation to ensure energy supply security of the country [2,15]. Subsidies that have been in effect so far have failed to facilitate Turkey's utilization of its RES potential for electricity generation [16].

In the literature, there are several studies which emphasize the harmful environmental impact of coal utilization and They suggest that coal is to be replaced with renewable energy sources (RES) as an efficient and effective solution to reduce the rapidly increasing GHG emissions of Turkey $[17,18]$.

Even though the RES investment has entered into a virtuous cycle of falling costs, there are still market barriers that do not exist for conventional power plants. Yet, the most important barrier is cost. Generally, initial capital investment costs of renewable power plants are higher than conventional power plants, and the major part of renewable power plants' cost is the initial investment cost. In order to avoid undesirable under-investment in renewable power plants and to make RES technologies technically and economically feasible, a wide variety of incentive mechanisms are being employed to promote electricity from RES (RES-E). Feed-in-Tariff (FiT), feed-in-premium (FiP), quota systems (green certificates or RPS-Renewable Portfolio Standard-), Investment subsidies, Auctions (Tendering), and Tax incentives/Fiscal measures have been used to promote RES-E investments [19]. Renewable energy subsidy mechanisms need to be used in combination and their efficiency and effectiveness should be evaluated at regular intervals. A combination of short-term (such as the direct investment subsidy recommended in this article) and long-term (such as the FiT mechanism, which Turkey currently relies on as its chief subsidy mechanism) subsidy mechanisms is an efficient mechanism that has made it possible to increase installed RES power [20,21,22,23,24].

Just like many other subsidy mechanisms, investment subsidy is also a widely used mechanism that brings returns in the short run. This mechanism is largely used in combination with other mechanisms in order to increase the installed capacity of RES [25,26].

Despite all the incentives and additional support, the desired installed power in RES-E has not been attained yet. The RES potential in Turkey is not yet adequately exploited except for hydropower. Turkey has been very slow in the process of attaining its 2023 energy policy targets. Therefore there is a need to implement new policies to foster the promotion of rich RES potential of Turkey. Turkey's energy policy agenda prioritizes energy supply security. As part of this agenda, tapping into RES is one of the three major objectives.

Turkey has abundant potential for RES [27, 28]. The country's realizable renewable energy potential is equal to 13\% of EU-27's total potential and Turkey's total RES-E generation potential is 240,165 GWh/yr for 138,000 MW economic potential. It has several different types of RES: 144,000 GWh/yr hydro (for 36,000 MW), 14,665 GWh/yr geothermal (for 2,000 MW), 60,000GWh/yr wind (for 48,000MW), 14,000 GWh/yr biomass (for 2,000 MW) and 7,500 GWh/yr solar (for 50,000 MW) potential [29, 30].

An analysis of the licensed and unlicensed power plants as of the end of February 2018 reveals that exploitation levels for wind, solar, biomass, and geothermal potential remain very low. Exploitation rates for hydraulic, wind, solar, geothermal, and biomass are respectively as follows: $72.26 \%, 13.6 \% 8$, 7.87\%, 53.18\%, and $13.07 \%$ [16].

To this day, capital subsidy incentive has not been applied to promote RES-E. This paper proposes capital subsidy incentive mechanism as a complementary mechanism to the already existing FiT incentive in order to overcome the market barriers that impede the RES-E deployment in Turkey. Economical and technical impacts of the proposed incentive have been analysed. In this context, additional installed power values were found for the planning horizon and RES deployment rates in the additional power according to the source types were determined. 
The rest of the paper is organized as follows: The second section presents a brief overview of the studies carried out in GEP and RES-E incentive mechanisms. The third section provides information on incentive mechanisms for renewable energy policies. The fourth section presents the details of existing incentive mechanisms and additional support available to RES-E in Turkey. The fifth section presents the mathematical model of the GEP. The sixth section gives a short explanation of a genetic algorithm (GA) and explains the data given as an input to the optimization model. The seventh section discusses the findings of the study. Based on the discussion of the findings, the last section offers concluding remarks and includes policy suggestions.

\section{Studies on GEP and RES incentive mechanisms}

Power GEP is an investment planning that deals with the expansion of the existing power system. A least cost GEP is to minimize the total cost to meet the forecasted demand within a prespecified reliability criterion over a planning horizon of typically 10-30 years [31,32,33]. Governments define their energy policies according to their priorities and objectives to meet growing energy demand. GEP is based on these energy policy constraints, together with other technical and economic constraints and supports energy policy of countries.

Power GEP defines the optimal size, type, location and commissioning date of additional power units within the planning horizon $[31,32,34]$. GEP problem can be solved by using mathematical and metaheuristic methods. Dynamic programming, decision tree, iterative algorithm, mixed integer programming, linear programming are mathematical methods that have been used to solve GEP problems. Meta-heuristic optimization methods such as ant colony optimization evolutionary programming, tabu search, honey bee algorithm, artificial immune system, differential evolution (DE) algorithm, GA and particle swarm optimization (PSO) have been successfully used to solve GEP [31, 34,35].

Yildirim et al. [35], describe an improved GA to solve the GEP for a 20-year planning horizon. Aghaei et al. [32] have used a Corrected Normal Boundary Intersection (CNBI) method to solve a Multi-period Multi-objective Generation Expansion Planning (MMGEP). Hemmati et al. [36] have used PSO method to solve the security and reliability constrained GEP in the presence of wind farm uncertainty. Rajesh et al. [34] have used the DE algorithm to solve GEP, and the impact of the inclusion of solar power plants was analyzed for two different planning horizons.

Murugan et al. [37] have applied an improved non-dominated sorting GA version II (NSGAII) to solve a multi-objective GEP problem.

Maturity in technological developments of renewable energy technologies and decrease in the costs of RES-E make these sources more acceptable worldwide [30]. Since the cost of RES-E is generally higher than electricity generated from conventional energy sources, governments create incentives for the penetration of RES-E in the electricity generation mix [20,38].

Financial incentives are important policy instruments available to encourage RES- E investors. Policy makers deploy different incentives to support RES-E. In order to be effective, these incentives have to contribute to ensure affordable, reliable, sustainable electricity [66].

By deploying these incentive mechanisms, governments indirectly aim to decrease $\mathrm{CO}_{2}$ emissions and improve energy supply security [21]. Morever, policy makers aim to increase employment and to foster technological innovation in RES by deploying these incentives [40]. Incentive policies need to be adjusted according to different government objectives or RES development stages [22].

Different types of incentive mechanisms are available to promote RES-E around the world. For the purpose of assessing the effectiveness and efficiency of incentive mechanisms applied to generate RESE, various studies have been undertaken: Butler et al. [41] and Haas et al.[42] have examined the performances of incentive mechanisms used in some European Union (EU) countries and FiT were found to be more effective and efficient than other mechanisms. Frondel et al. [40] argue that government intervention can serve to support renewable energy technologies through mechanisms such as European Trading Scheme and funding for R\&D. Technological improvements in the renewable 
technologies production chain reduce costs and the subsidies will be eliminated as renewable power plants become competitive with conventional power plants [20].

\section{Incentive mechanisms for renewable energy support policy}

There are various incentive mechanisms utilised to make renewable power plants more competitive against conventional power plants. Table 1 shows characterization of incentive mechanisms for promoting RES-E [43,44,45].

As capital subsidy and FiT incentive mechanisms have been proven to be the most successful mechanisms in attracting private investment in RES-E and being the core subject of this paper, a brief discussion have been made for these mechanisms.

Capital subsidy is one of the most broadly used incentive mechanisms that governments provide for the commissioning of renewable power plants. In this mechanism, governments grant different capital subsidies by which a percentage of the total capital cost for the investment is subsidized [43, 44, 45]. Capital subsidy scheme has a low transaction cost relative to other schemes. However, this scheme usually depends directly on the public treasury and therefore alters with a changing political agenda. Policy makers should consider the factors that influence the mechanism's effectiveness and efficiency to create a sustainable market before choosing to apply the mechanism. A phase out time has to be defined for capital subsidy to ensure efficiency improvements in RES technologies.

Table 1. RES-E incentive mechanisms.

\begin{tabular}{|c|c|c|c|c|}
\hline & & \multicolumn{2}{|c|}{ Direct } & \multirow[t]{2}{*}{ Indirect } \\
\hline \multirow[b]{2}{*}{ 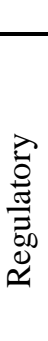 } & & With price priority & With capacity priority & \\
\hline & $\begin{array}{l}\text { Investment } \\
\text { focused } \\
\text { Generation } \\
\text { based }\end{array}$ & $\begin{array}{l}\text { Capital subsidy, } \\
\text { Grants, Rebates, } \\
\text { Loans } \\
\text { Feed-in tariff, } \\
\text { Net metering / Net } \\
\text { billing }\end{array}$ & $\begin{array}{l}\text { Tendering, Quota, } \\
\text { Tradable renewable } \\
\text { energy certificates }\end{array}$ & $\begin{array}{l}\text { Environmental taxes, } \\
\text { Other incentives } \\
\text { (licensing priority,grid } \\
\text { connection priority etc. }\end{array}$ \\
\hline \multirow{2}{*}{ 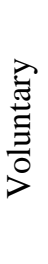 } & $\begin{array}{l}\text { Investment } \\
\text { focused }\end{array}$ & $\begin{array}{l}\text { Share holder } \\
\text { programmes, } \\
\text { Contribution } \\
\text { programmes }\end{array}$ & & \multirow[t]{2}{*}{ Voluntary agreements } \\
\hline & $\begin{array}{c}\text { Generation } \\
\text { based }\end{array}$ & Green tariffs & & \\
\hline \multirow{2}{*}{ 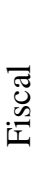 } & $\begin{array}{l}\text { Investment } \\
\text { focused }\end{array}$ & & & \multirow[t]{2}{*}{ Tax incentives } \\
\hline & $\begin{array}{c}\text { Generation } \\
\text { based }\end{array}$ & & & \\
\hline
\end{tabular}

FiT offers purchasing electricity through guaranteed payment per kWh generation (currency/kWh) for a pre-determined period of time. Payment type differs according to countries. The FiT is a regulatory price-based mechanism which is widely used to promote the RES-E deployment. This incentive mechanism which has been designed according to the economic, technical and social conditions of the countries has played an important role in promoting the RES-E deployment rate [22, 38, 39, 46, 47]. Payment in this mechanism may be at a fixed price which is market- independent or at a premium price which is market-dependent. 
Determining an appropriate FiT is a highly challenging task. An appropriate FiT makes RES projects more attractive to investors, improves resource efficiency and limits the cost to society. Technology specified incentive scheme encourages investments in more expensive RES technologies and has lower risk involved for investors. This mechanism eliminates purchase and price risks [38]. FiT mechanism aims to support the technological maturity of renewable power technologies with contracts ranging from 10 to 25 years. Renewable power generation penetration into the energy mix has the highest impact on FiT's sustainability [47].

An analysis of the energy policies of the countries that transition into RES [48,49,50,51], Germany in particular, reveals that the most efficient and effective RES-based electricity generation incentive mechanism is the source-dependent and long-term FiT mechanism. The success of this core RES-E incentive scheme relies on a combination of a predictable legislation and robust policy framework. The scheme is implemented along with a set of complementary policies such as R\&D and innovation subsidies, capital investment subsidies, direct funding, tax exemptions, grid access support and emissions trading system $[48,49,50,52]$.

FiT and direct capital investment subsidies have been the mostly prefered types of financial incentives to promote RES. These incentive mechanisms have led to the largest deployment quantities with the lowest costs [52,53, 54, 55]. Direct subsidy scheme has yielded good results in many EU countries to promote RES-E especially in PV sector [54].

\section{The existing incentive mechanism in Turkey}

Technology specified FiT incentive mechanism is used as a core national renewable energy support policy instrument to promote RES-E in Turkey. The FiT rates and maximum possible FiT rates in case of domestic component bonuses are given in Table 2 [56].

Table 2. RES-E feed-in tariffs [56].

\begin{tabular}{|c|c|c|c|}
\hline Technology & Capacity & $\begin{array}{l}\text { FiT rate } \\
\text { (\$/kWh) }\end{array}$ & $\begin{array}{l}\text { Maximum possible FiT } \\
\text { rate in case of } \\
\text { domestically } \\
\text { manufactured } \\
\text { components }(\$ / \mathrm{kWh})\end{array}$ \\
\hline Hydro & \multirow{6}{*}{ All sizes } & 0.073 & 0.096 \\
\hline Wind & & 0.073 & 0.110 \\
\hline Geothermal & & 0.105 & 0.132 \\
\hline Biomass (including landfill gas) & & 0.133 & 0.189 \\
\hline Solar & & 0.133 & 0.200 \\
\hline CSP & & 0.133 & 0.225 \\
\hline
\end{tabular}

In order to support RES-E, further regulations have been pursued [57,58,59,60]: Table 3 provides existing incentives and support mechanisms of RES-E in Turkey.

Table 3. Existing incentives and other support mechanisms of RES-E in Turkey. 


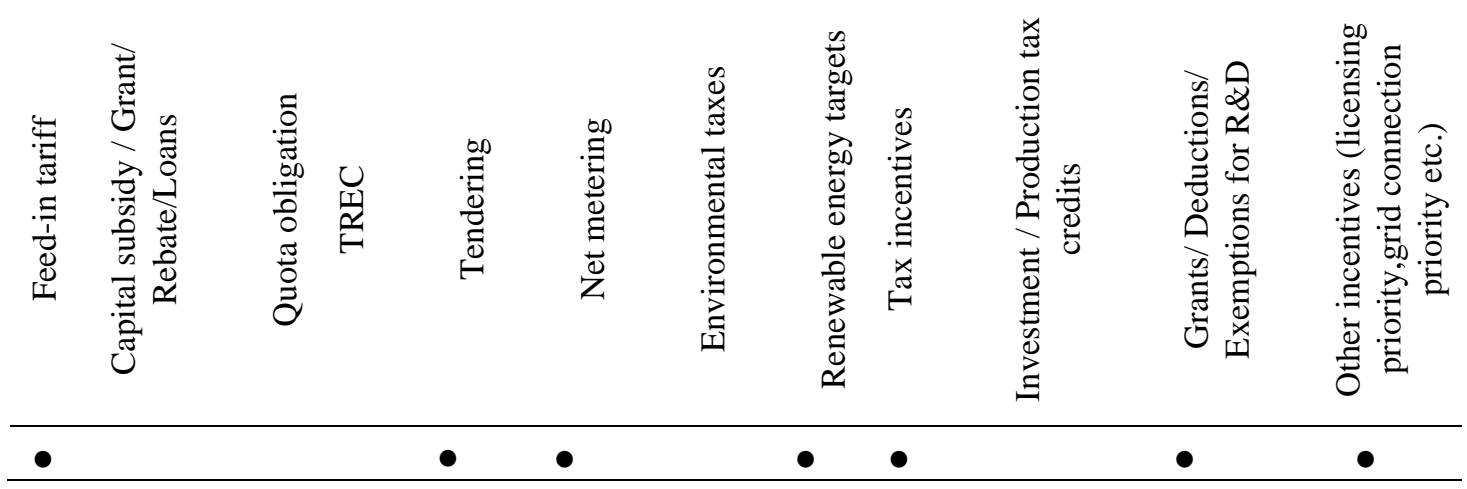

Although FiT and some other supports have been applied to promote RES-E, direct capital investment subsidy mechanism has not yet been applied for promoting RES-E in Turkey.

\section{GEP model}

In this study, GA was used by considering the features possessed by the GEP problem. For the solution of the GEP problem, determination of the objective function and inputs for the model have been defined and construction and programming of an algorithm were realized to find the lowest value of the objective function.

\subsection{Objective function}

The objective function is a linear / non-linear function of multiple variables that contains investment costs of energy generation units to be installed during the planning period, as well as operation and maintenance (O\&M) costs and constraints. For this reason, firstly, the planning horizon is determined. In this study, the planning horizon is set as 16 years. The notation used in the study is as follows:

Z total cost in planning horizon,

$Z_{c} \quad$ total investment cost in the planning horizon,

$Z_{o m} \quad$ total O\&M cost in the planning horizon,

$C_{j t} \quad$ unit investment cost for $j$ type unit to be put into operation in the year $t$,

$C_{j 0} \quad$ unit investment cost for $j$ type unit for the first year of the planning horizon,

$x_{j t} \quad$ total power capacity of $j$ type units to be put into operation in the year $t$,

$n_{j t} \quad$ number of $j$ type units to be put into operation in the year $t$,

$X_{j \max } \quad$ maximum power capacity of a single $j$ type unit,

$f_{j t k} \quad$ O\&M cost of $j$ type unit to be installed in the year $t$ and will be operated until the end of planning horizon,

$f_{j 0} \quad$ O\&M cost of $j$ type unit that is in operation in the first year of the planning horizon,

$y_{j t} \quad$ energy value to be met by $j$ type units to be put into operation in the year $t$, 
$K$ number of years that a unit will remain in operation until the end of the planning horizon,

$k \quad$ number of years that a unit remained in operation since it was put into operation,

$c_{j t} \quad$ capacity coefficient of $j$ type unit in the year $t$,

$P_{t} \quad$ peak power value of the year $t$,

$m \quad$ reserve capacity coefficient $(1 \geq m \geq 0)$,

$E_{t} \quad$ energy demand in the year $t$,

$h_{j t} \quad$ theoretical working time of $j$ type unit per year,

$e_{j c} \quad$ investment cost escalation rate for $j$ type unit,

i interest rate,

$\xi_{j} \quad$ effecting rate of additional expenses to cost related to environmental problems to be created by $j$ type unit,

$r_{j t} \quad$ capital recovery factor of $j$ type unit installed in the year $t$,

$L_{j} \quad$ economic lifetime of $j$ type unit,

$e_{j f} \quad$ O\&M cost escalation rate of $j$ type unit,

$R_{\text {jmax }} \quad$ maxium reserve capacity of unit type $j$.

The objective function in the GEP was found by using Eq.(1) and (2) as the total of $Z_{c}$ and $Z_{o m}$ functions and penalty that will bring the investment and O\&M costs to the lowest value together. Eq. (2) is a modified version of the objective function used in reference [61]. Penalty is the cost of violated reliability constraints.

$x_{j t}$ values are calculated by using $n_{j t}$ values referred to as the decision variable for the model. $n_{j t}$ must be determined in a manner that will meet reliability constraints and simultaneously achieve the lowest value of the objective function.

$$
Z=Z_{c}+Z_{\text {om }}+\text { penalty }
$$

$Z=\sum_{j=1}^{J} \sum_{t=1}^{T} C_{j t} x_{j t}+\sum_{j=1}^{J} \sum_{t=1}^{T} \sum_{k=1}^{K} f_{j t k} y_{j t}+$ penalty

Here;

$x_{j t}=n_{j t} X_{j \max }$ 
Unit costs are evaluated by considering the economic and technical factors that may change between the dates when the unit is planned and its construction is realized, and by considering the environmental factors. The unit investment costs of units installed in the year $t$ were calculated with the Eq.(4) by using the first-year values. In the same manner, the O\&M costs of units installed in the year $t$ were calculated with the Eq.(5) by using the first-year values $f_{j 0}$, where $f_{j t k}$ is the O\&M cost of $j$-type unit, which is installed in year $t$ and will be operated $k$ years until the end of planning term. Again, economic and technical factors of O\&M cost may change between the years a unit is planned to be installed and it starts operation.

$$
\begin{aligned}
C_{j t} & =C_{j 0}\left[\left(1-e_{j c}\right)(1+i)\right]^{-t} r_{j t} \xi_{j} \\
f_{j t k} & =f_{j 0}\left[\left(1-e_{j f}\right)(1+i)\right]^{-t}
\end{aligned}
$$

In the study, to meet the investment costs, the capital recovery factor, as given in Eq. (6), is used. The purpose of using this factor is to ensure recognition of an expense of investment cost with higher shares in the first years and with lower shares towards the end of economic lifetime of the units. The capital recovery factors are determined by considering the economic lifetime $\left(L_{j}\right)$ of units.

$r_{j t}=\frac{2}{L_{j}\left(L_{j}+1\right)} \sum_{t=1}^{T}\left(L_{j}-t+1\right)$

\subsection{Constraints}

Constraints that will ensure reliability while minimizing the cost are given below.

Contsraint-1: For each year, the higher limit value of total available capacity must meet $P_{t}$ peak power in that year with a defined reliability. The constraint defining this condition is given by Eq. (7).

$$
\sum_{j=1}^{J} \sum_{t=1}^{T} c_{j t} X_{j t} \geq P_{t}(1+m)
$$

Constraint-2: For a defined year, total energy generations of units in operation must be sufficient to meet the energy demand of that year. The constraint ensuring this condition is given by Eq. (8) and Eq. (9).

$$
\begin{aligned}
& \sum_{j=1}^{J} \sum_{t=1}^{T} y_{j t} \geq E_{t} \\
& y_{j t}=c_{j t} x_{j t} h_{j t}
\end{aligned}
$$

Constraint-3: The total power capacity of $j$ type units to be put into operation in the year $t$ must be smaller than or equal to the highest limit of reserve capacity $R_{j \max }$ that may be installed related to $j$ type unit. This condition is given in Eq. (10). While determining the highest capacity values that may be 
installed, domestic fuel generation amounts, reserves, importable fuel quantities and energy policy targets must also be considered.

$$
\sum_{t=1}^{T} x_{j t} \leq R_{j \operatorname{maz}}
$$

Constraint-4: To limit use of imported sources and to be able to consider a low-energy value to be generated in hydroelectric units in arid climate conditions, available capacity for all source types in any year may not exceed $35 \%$ of available capacity of all candidate unit types installed in that year. This is given by Eq. (11).

$c_{j t} X_{j t} \leq\left(\sum_{j=1}^{J} c_{j t} x_{j t} 0.35\right)$

Maximum energy that may be generated by generation units decreases as units degrade. Based on the year the unit is installed, the energy value it may generate depending on the number of years it is in operation is calculated by using the capacity coefficient $\left(c_{j t}\right)$ given by Eq. (12).

$c_{j t}=c_{j 0}(1-0.007)^{k}$

\section{Planning method and parameters}

The goal of optimization technique is to efficiently explore the search space in order to find the optimal solution. Exploring all the feasible solutions is a difficult task if the search space is large and the evaluation process takes a very long time. For this reason, in problems having large search space, a method which tries to explore different areas in the search space in a smart way to find optimal solution in less cost and short computation time is required [62].

In order to cope with the limitations of the classical optimization techniques, many different metaheuristic optimization techniques have been developed. These techniques are designed to handle nonconvex problems, since they have mechanisms to escape the local optimum. The meta-heuristic optimization algorithms are simple in nature, have an easy implementation procedure and provide a better computation time performance as compared to conventional optimization techniques. These techniques have proved their ability to solve GEP problems[63, 64].

There has been a growing interest in applying metheuristic techniques to solve GEP problems and GA is one of the most commnly used technique among these techniques [ 63, 64, 65, 66]. Compared with other metheuristic techniques, GA's are suitable for discovering large and complex search spaces and mutatiton operator prevents the GA from becoming trapped in a local minima. GA discover large search spaces relatively rapidly and could find the global optima in a short time. Calculations of the GEP problem could be speeded up due to its inherently parallel feature. This feature can significantly reduce the CPU time required [67,68]. GA is commonly used as a main algorithm in hybrid optimization methods [66]. Considering all the aforementioned advantages, we preferred to apply GA to solve GEP problem.

An integer coded GA was used for the optimization algorithm in this study. The chromosome structure of the GA used in the optimization is given in Fig. 1. The roulette-wheel selection method was the preferred selection method, and the rank-based assignment method was used for fitness value assignment. Population size, crossover rate and mutation rate were taken as 400, 1.0, and 0.005, 
respectively. Previous studies $[61,69,70]$ that were conducted by the co-authors of this paper provide more detailed information on the application of GA to a GEP problem.

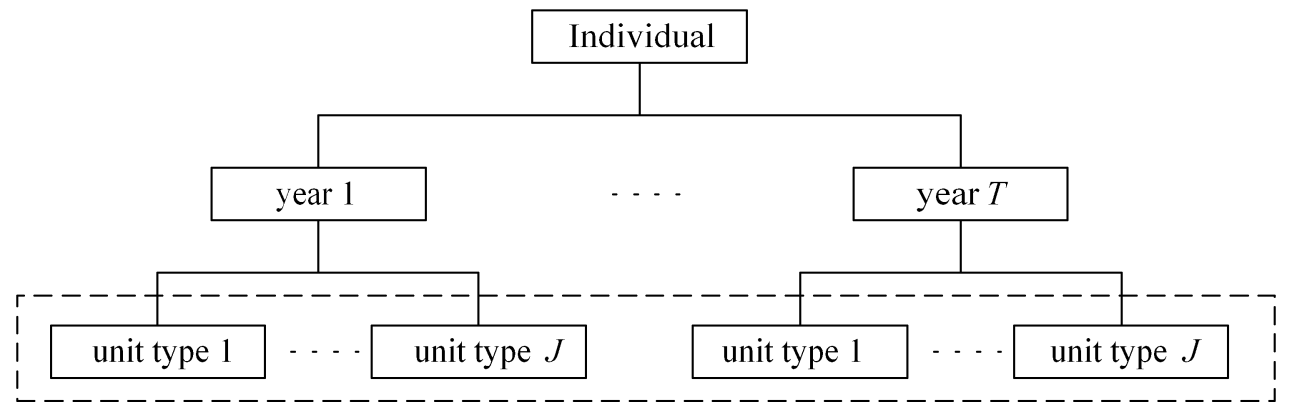

Fig. 1. Chromosome structure of GA.

In the study, a GEP having 11 candidate unit types, including renewable power units, is analyzed with a GA. The planning horizon is taken as 16 years and the problem was solved to find which types of additional units will be constructed, how many units will be added and when these units will be commissioned.

In the planning stage, one of the most important data given as an input to the model is the power demand that must be met during the planning horizon. Growth trends in historical loads form a basis for future load forecasts. The cumulative power demand (in column 2) and energy demand (in column 4) values given in Table 4 [71], which were stated in the generation capacity projection of Turkish Electricity Transmission Co. (TEİAŞ), were taken as forecasted demand. These demand values were determined by subtracting the already installed capacity value in that year from that year's demand value. The values in column 3 and 5 in Table 4 were determined by means of GEP that show they meet the demand values in column 2 and 4, respectively.

Table 4. Demand values and planning results for the planning horizon.

\begin{tabular}{crrrr}
\hline Year & $\begin{array}{c}\text { Cumulative } \\
\text { power demand } \\
\text { in each year } \\
\text { (MW) }\end{array}$ & $\begin{array}{c}\text { Cumulative } \\
\text { planned power } \\
\text { capacity in each } \\
\text { year (MW) }\end{array}$ & $\begin{array}{c}\text { Cumulative } \\
\text { energy demand } \\
\text { in each year } \\
\text { (GWh) }\end{array}$ & $\begin{array}{c}\text { Cumulative } \\
\text { planned energy } \\
\text { generation } \\
\text { capacity in each } \\
\text { year (GWh) }\end{array}$ \\
\hline $\mathbf{1}$ & 2,200 & 7,424 & 15,280 & 50,260 \\
$\mathbf{2}$ & 4,565 & 8,505 & 32,535 & 58,218 \\
$\mathbf{3}$ & 7,080 & 12,137 & 50,875 & 83,797 \\
$\mathbf{4}$ & 9,878 & 12,478 & 70,465 & 86,585 \\
$\mathbf{5}$ & 13,025 & 16,168 & 91,325 & 112,440 \\
$\mathbf{6}$ & 16,465 & 18,267 & 113,550 & 127,240 \\
$\mathbf{7}$ & 20,105 & 20,152 & 137,180 & 140,298 \\
$\mathbf{8}$ & 23,975 & 25,480 & 162,295 & 176,956 \\
$\mathbf{9}$ & 28,093 & 28,105 & 189,030 & 194,309 \\
$\mathbf{1 0}$ & 32,579 & 32,618 & 218,152 & 225,824 \\
$\mathbf{1 1}$ & 37,380 & 37,505 & 249,313 & 258,620 \\
$\mathbf{1 2}$ & 42,516 & 42,662 & 282,655 & 292,471 \\
$\mathbf{1 3}$ & 48,012 & 48,103 & 318,330 & 328,750 \\
$\mathbf{1 4}$ & 53,893 & 53,903 & 356,504 & 366,865 \\
$\mathbf{1 5}$ & 60,186 & 60,286 & 397,349 & 410,736 \\
$\mathbf{1 6}$ & 66,919 & 66,919 & 441,053 & 454,678 \\
\hline & & & & \\
\hline
\end{tabular}


The technical and economic parameters of candidate unit types for the first year of the planning horizon are given in Table 5.

Table 5. Technical and economic parameters for candidate unit types [69,70].

\begin{tabular}{|c|c|c|c|c|c|c|c|c|c|}
\hline$j$ & Unit type & $X_{\text {jmax }}(\mathrm{MW})$ & $\begin{array}{c}C_{j 0} \\
(\$ / \mathrm{kW})\end{array}$ & $\begin{array}{c}f_{j 0} \\
(\$ / \mathrm{kW}- \\
\text { year) }\end{array}$ & $\begin{array}{c}C_{j 0} \\
(\%)\end{array}$ & $e_{j c}, e_{j f}$ & $k j$ & $h_{j}$ (hour) & $L_{j}$ (year) \\
\hline 1 & Natural gas & 700 & 500 & 273.50 & 85.00 & 0.03 & 0.007 & 7,000 & 30 \\
\hline 2 & Lignite & 350 & 1,146 & 335.40 & 85.00 & 0.03 & 0.007 & 6,500 & 40 \\
\hline 3 & Hard coal & 300 & 1,084 & 403.80 & 85.00 & 0.03 & 0.007 & 6,500 & 40 \\
\hline 4 & Imported coal & 500 & 1,110 & 321.90 & 85.00 & 0.03 & 0.007 & 6,500 & 40 \\
\hline 5 & Fuel-oil & 150 & 1,280 & 357.80 & 77.02 & 0.03 & 0.007 & 6,500 & 40 \\
\hline 6 & Nuclear & 1,000 & 2,000 & 657.00 & 85.00 & 0.03 & 0.007 & 7,000 & 60 \\
\hline 7 & Hydro & 500 & 1,350 & 4.40 & 50.00 & 0.03 & 0.007 & 7,000 & 80 \\
\hline 8 & Wind & 45 & 1,912 & 61.77 & 30.00 & 0.03 & 0.007 & 3,000 & 25 \\
\hline 9 & Geothermal & 50 & 3,000 & 145.68 & 75.00 & 0.03 & 0.007 & 8,000 & 40 \\
\hline 10 & Biomass & 30 & 2,599 & 116.88 & 85.00 & 0.03 & 0.007 & 8,000 & 20 \\
\hline 11 & Solar & 5 & 3,500 & 15.05 & 11.00 & 0.03 & 0.007 & 2,640 & 25 \\
\hline
\end{tabular}

The unit investment costs vary according to the unit types. For the first year of planning, the unit investment cost $C_{j 0}$ for a $j$ type unit is given in Table 5. The unit investment cost of a unit $j$ to be installed in the year $t, C_{j t}$, is calculated with Eq. (4).

In calculating unit investment costs, capital recovery factors given in Eq. (6) must be taken into consideration. Depending on the developing technology, electricity generation units are designed to minimize the negative effects on the environment. By considering this situation in unit investment costs, $\xi_{j}$ rate is accepted as “ 1 ". For the first year of the planning horizon, the O\&M cost $f_{j 0}$ of a $j$ type unit is given in Table 5. The O\&M cost $f_{j t k}$ of a unit $j$ to be installed in the year $t$ is calculated with Eq. (5). The capacity factor $c_{j 0}$ values of unit types used in the planning study are given in Table 5 . By considering the annual $0.7 \%$ decrement of capacity factors, the capacity coefficient of any $\mathrm{j}$ type unit related to the year $t$ is calculated by using Eq. (12).

\section{Analysis of results for capital subsidy in the GEP}

After selecting the GA parameters, least-cost GEP was carried out to determine the type and number of candidate plants that meets forecasted demand within prespecified constraints over a planning horizon of 16 years.

Firstly, optimization was made without the subsidy (without-subsidy case) in order to set a benchmark. Further optimization results, with different levels of capital investment subsidies were compared with this benchmark. The results of the without-subsidy case, the type and number of candidate plants types are given in Table 6 .

Table 6. Numbers of new units to be added during the planning horizon.

Year CANDIDATE SOURCE TYPES


Ozcan et. al

\begin{tabular}{|c|c|c|c|c|c|c|c|c|c|c|c|}
\hline & 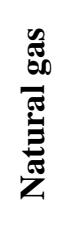 & 营 & 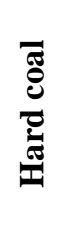 & 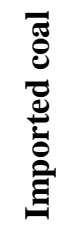 & $\begin{array}{l}\overline{0} \\
\bar{d} \\
\bar{g}\end{array}$ & $\frac{\tilde{J}}{\underline{Z}}$ & $\stackrel{8}{8}$ & 吾 & 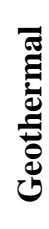 & 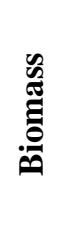 & 흥 \\
\hline 1 & 4 & 6 & 0 & 6 & 0 & 0 & 1 & 0 & 0 & 18 & 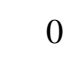 \\
\hline 2 & 0 & 0 & 0 & 0 & 0 & 0 & 3 & 0 & 0 & 15 & 0 \\
\hline 3 & 0 & 0 & 0 & 0 & 0 & 0 & 13 & 4 & 0 & 15 & 1 \\
\hline 4 & 0 & 0 & 0 & 0 & 0 & 0 & 0 & 0 & 1 & 15 & 1 \\
\hline 5 & 4 & 0 & 0 & 1 & 1 & 0 & 2 & 1 & 1 & 12 & 0 \\
\hline 6 & 1 & 1 & 0 & 0 & 0 & 0 & 4 & 1 & 0 & 12 & 0 \\
\hline 7 & 0 & 3 & 0 & 0 & 0 & 0 & 3 & 1 & 0 & 14 & 0 \\
\hline 8 & 4 & 0 & 0 & 3 & 3 & 0 & 4 & 4 & 0 & 16 & 1 \\
\hline 9 & 0 & 0 & 0 & 2 & 8 & 0 & 2 & 10 & 1 & 14 & 0 \\
\hline 10 & 3 & 0 & 0 & 2 & 1 & 0 & 6 & 1 & 1 & 16 & 0 \\
\hline 11 & 1 & 1 & 0 & 6 & 0 & 0 & 6 & 1 & 3 & 1 & 4 \\
\hline 12 & 1 & 0 & 0 & 9 & 0 & 0 & 3 & 9 & 0 & 5 & 0 \\
\hline 13 & 3 & 5 & 0 & 3 & 1 & 0 & 3 & 11 & 0 & 7 & 0 \\
\hline 14 & 1 & 4 & 0 & 8 & 1 & 0 & 1 & 11 & 2 & 14 & 1 \\
\hline 15 & 7 & 2 & 1 & 2 & 3 & 0 & 1 & 2 & 1 & 9 & 1 \\
\hline 16 & 2 & 7 & 0 & 7 & 2 & 0 & 2 & 0 & 0 & 3 & 0 \\
\hline
\end{tabular}

According to the candidate unit capacities and unit numbers given in Table 5 and Table 6 respectively, a total 95,700 MW installed power was found for future additions in planning horizon as shown in Table 7.

Table 7. Development of available capacity (MW).

\begin{tabular}{|c|c|c|c|c|c|c|c|c|c|c|c|c|c|}
\hline \multirow[b]{2}{*}{ Year } & \multicolumn{13}{|c|}{ CANDIDATE SOURCE TYPES } \\
\hline & 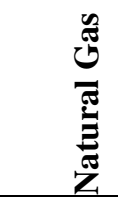 & 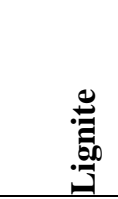 & 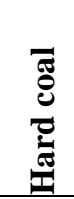 & 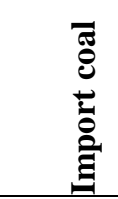 & $\begin{array}{l}\overline{0} \\
\overline{1} \\
\overline{\underline{I}} \\
\overline{\underline{I}}\end{array}$ & $\frac{\vec{d}}{\mathrm{~g}}$ & 胥 & $\overrightarrow{3}$ & لَّ & 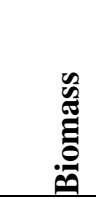 & 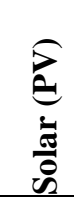 & 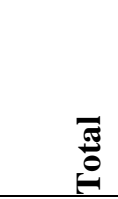 & 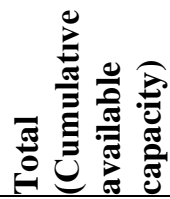 \\
\hline 1 & 2,800 & 2,100 & 0 & 3,000 & 0 & 0 & 500 & 0 & 0 & 540 & 0 & 8,940 & 7,424 \\
\hline 2 & 0 & 0 & 0 & 0 & 0 & 0 & 1,500 & 0 & 0 & 450 & 0 & 1,950 & 8,505 \\
\hline 3 & 0 & 0 & 0 & 0 & 0 & 0 & 6,500 & 180 & 0 & 450 & 50 & 7,180 & 12,137 \\
\hline 4 & 0 & 0 & 0 & 0 & 0 & 0 & 0 & 0 & 50 & 450 & 50 & 550 & 12,478 \\
\hline 5 & 2,800 & 0 & D & 500 & 150 & 0 & 1,000 & 45 & 50 & 360 & 0 & 4, & 68 \\
\hline 6 & 700 & 350 & 0 & 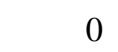 & 0 & 0 & 2,000 & 45 & 0 & 360 & 0 & 3 & 18,267 \\
\hline 7 & 0 & 1,050 & 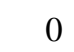 & 0 & 0 & 0 & 1,500 & 45 & 0 & 420 & 0 & 3,015 & 20,152 \\
\hline 8 & 2,800 & 0 & 0 & 1,500 & 450 & 0 & 2,000 & 180 & 0 & 480 & 50 & 7,460 & 25,480 \\
\hline 9 & 0 & 0 & 0 & 1,000 & 1,200 & 0 & 1,000 & 450 & 50 & 420 & 0 & 4,120 & 28,105 \\
\hline 10 & 2,100 & 0 & 0 & 1,000 & 150 & 0 & 3,000 & 45 & 50 & 480 & 0 & 6,825 & 32,618 \\
\hline 11 & 700 & 350 & 0 & 3,000 & 0 & 0 & 3,000 & 45 & 150 & 30 & 200 & 7,475 & 37,505 \\
\hline 12 & 700 & 0 & 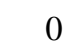 & 4,500 & 0 & 0 & 1,500 & 405 & 0 & 150 & 0 & 7,255 & 42,662 \\
\hline 13 & 2,100 & 1,750 & 0 & 1,500 & 150 & o & 1,500 & 495 & 0 & 210 & 0 & 7,705 & 48,103 \\
\hline 14 & 700 & 1,400 & 0 & 4,000 & 150 & 0 & 500 & 495 & 100 & 420 & 50 & 7,815 & 53,903 \\
\hline 15 & 4,900 & 700 & 300 & 1,000 & 450 & 0 & 500 & 90 & 50 & 270 & 50 & 8,310 & 60,286 \\
\hline 16 & 1,400 & 2,450 & 0 & 3,500 & 300 & 0 & 1,000 & 0 & 0 & 90 & 0 & 8,740 & 66,919 \\
\hline Total & 21,700 & 10,150 & 300 & 24,500 & 3,000 & 0 & 27,000 & 2,520 & 500 & 5,580 & 450 & 95,700 & \\
\hline
\end{tabular}


When the capacities (Table 4, column 3) and energy values (Table 4, column 5) of units commissioned after the first year of planning are examined, it is seen that forecasted demands in Table 4 (column 2 and column 4) can be met for each of the planning horizon years within the prespecified constraints.

The total installed power of non-hydro RES was found as 9,050 MW as shown in Table 7. The installed power percentages of units for future additions in the planning horizon are given in Fig. 2. The ratio of non-hydro RES, which consists of wind, geothermal, biomass and solar energy, to overall installed power were found as $9.45 \%$.

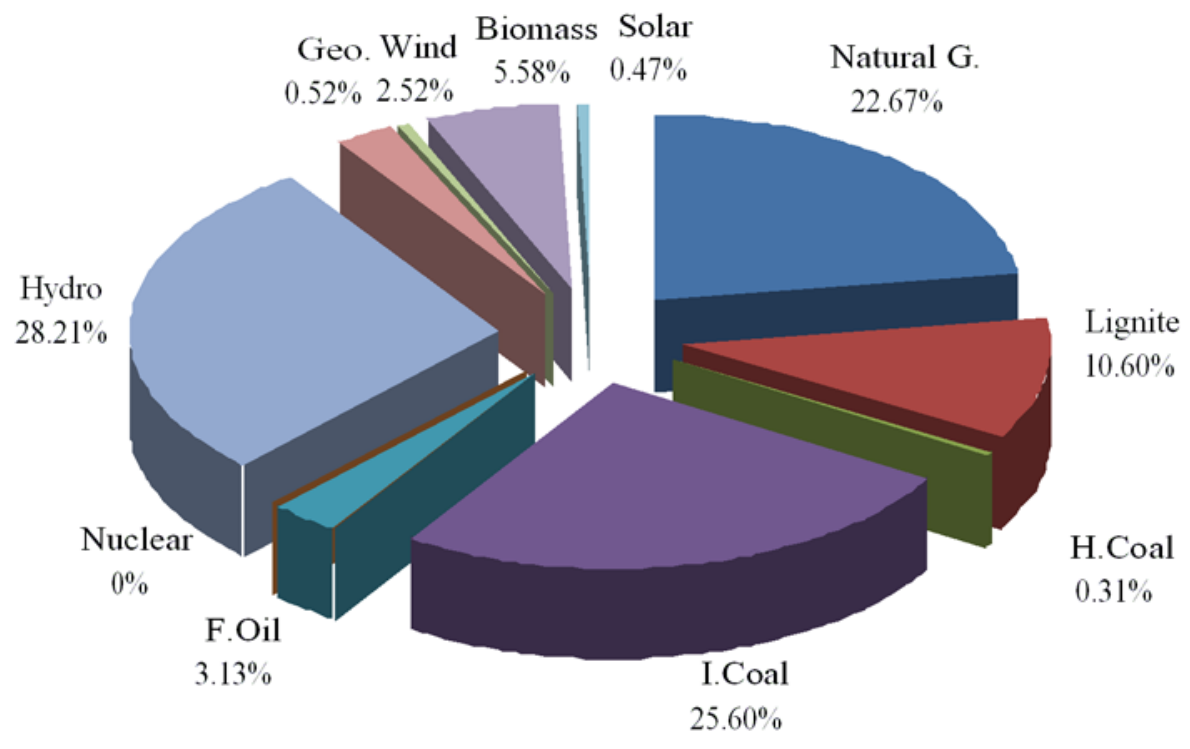

Fig. 2. Installed power rates without investment subsidy for non-hydro renewables.

Secondly, planning was carried out for three different direct capital investment subsidy rates (20\%, 40\%, $50 \%$ ) to cover a percentage of non-hydro renewable units' investment costs. Investment costs following the application of different investment subsidy rates for non-hydro renewables are shown in Table 8.

Table 8. Investment costs after different subsidy rates for non-hydro renewables.

\begin{tabular}{llrrrr}
\hline Incentive rate & $0 \%$ & $20 \%$ & $40 \%$ & $50 \%$ \\
\hline $\mathrm{j}$ & Unit type & $\begin{array}{c}C_{j 0} \\
(\$ / \mathrm{kW})\end{array}$ & $\begin{array}{c}C_{j 0} \\
(\$ / \mathrm{kW})\end{array}$ & $\begin{array}{c}C_{j 0} \\
(\$ / \mathrm{kW})\end{array}$ & $\begin{array}{c}C_{j 0} \\
(\$ / \mathrm{kW})\end{array}$ \\
\hline 1 & Natural gas & 500 & 500 & 500 & 500 \\
2 & Lignite & 1,146 & 1,146 & 1,146 & 1,146 \\
3 & Hard coal & 1,084 & 1,084 & 1,084 & 1,084 \\
4 & Imported coal & 1,110 & 1,110 & 1,110 & 1,110 \\
5 & Fuel-oil & 1,280 & 1,280 & 1,280 & 1,280 \\
6 & Nuclear & 2,000 & 2,000 & 2,000 & 2,000 \\
7 & Hydro & 1,350 & 1,350 & 1,350 & 1,350 \\
8 & Wind & 1,912 & 1,530 & 1,147 & 956 \\
9 & Geothermal & 3,000 & 2,400 & 1,800 & 1,500 \\
10 & Biomass & 2,599 & 2,079 & 1,559 & 1,300 \\
11 & Solar & 3,500 & 2,800 & 2,100 & 1,750 \\
\hline
\end{tabular}


The total installed power of the non-hydro renewables was calculated as 9,540 MW when investment cost is reduced by $20 \%$ (Table 8 ). The installed power percentages of units for future additions in the planning horizon are given in Fig. 3. The ratio of the non-hydro renewables to overall installed power was estimated as $9.98 \%$.

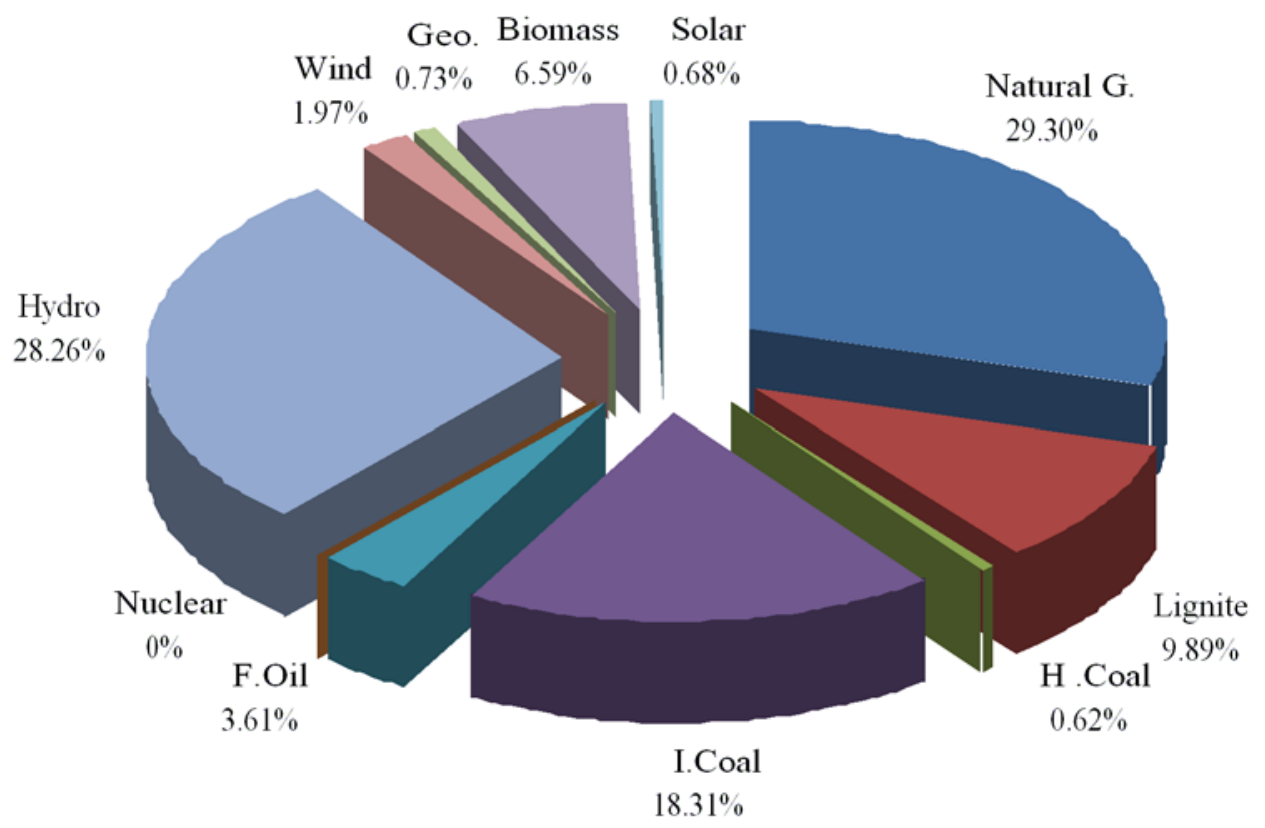

Fig. 3. Installed power rates under the condition of $20 \%$ investment subsidy for non-hydro renewables.

The total installed power of the non-hydro renewables was found as 11,740 MW when investment costs are reduced by $40 \%$ (Table 8 ). The installed power percentages of units for future additions in the planning horizon are given in Fig. 4. The ratio of the non-hydro renewables to overall installed power was estimated to be $12.0 \%$.

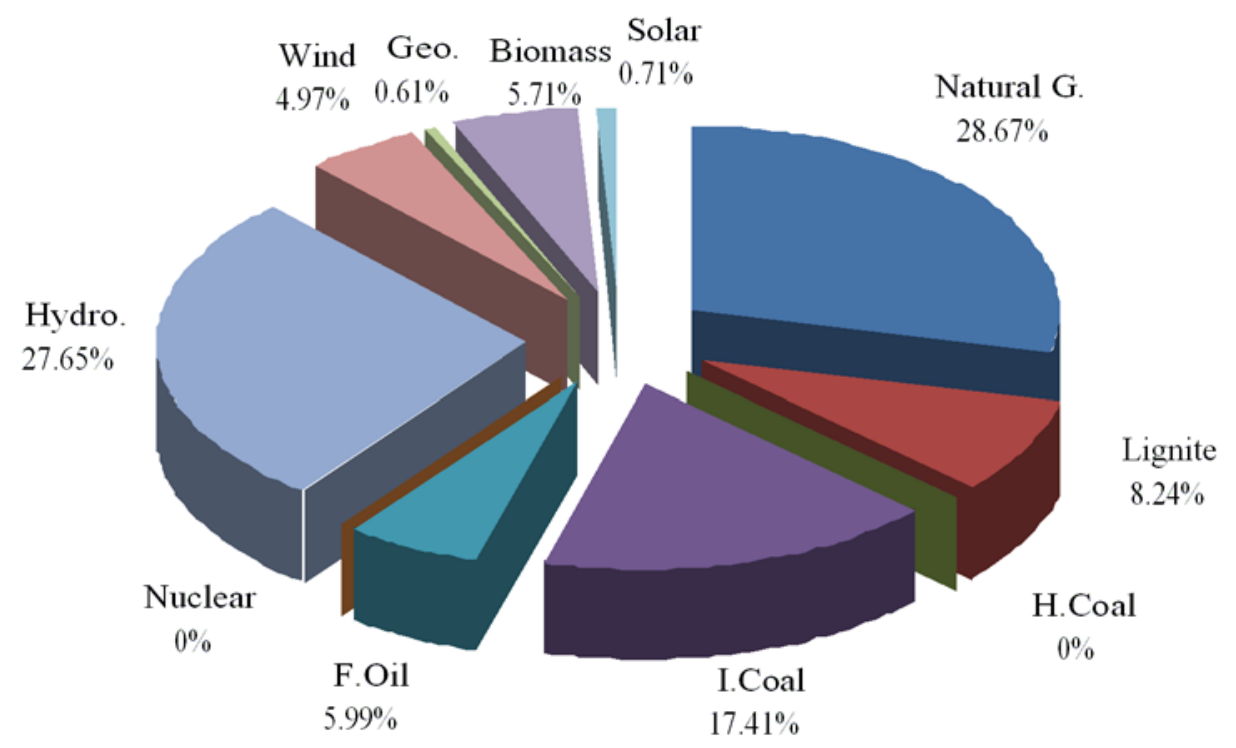

Fig. 4. Installed power rates under the condition of $40 \%$ investment subsidy for non-hydro renewables. 
The total installed power of the non-hydro renewables was calculated as 13,405 MW when investment costs are reduced by $50 \%$ (Table 8). The installed power percentages of units for future additions in the planning horizon are given in Fig. 5.

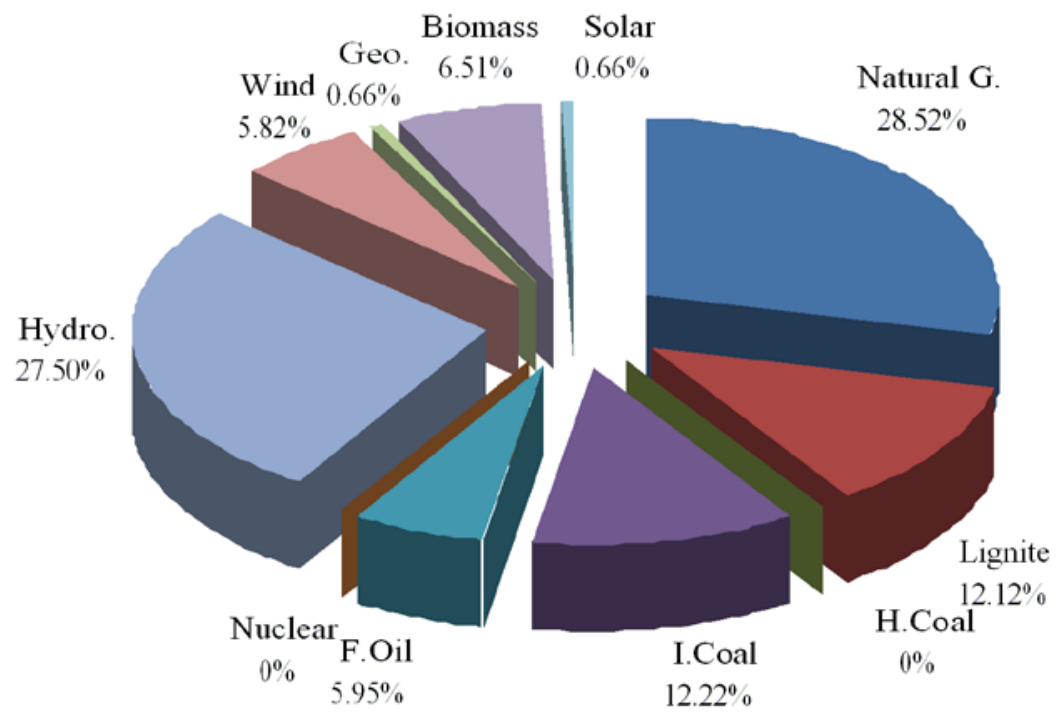

Fig. 5. Installed power rates under the condition of 50\% investment subsidy for non-hydro renewables.

Finally, the ratio of the non-renewables to overall installed power was estimated as $13.65 \%$.

\section{Conclusion}

Increase in the subsidy rates for non-hydro renewable power plants has not resulted in remarkable changes in lignite shares. NPP was not selected as a solution in any case since it has the most expensive cost. It has been observed that the share of imported coal decreases monotonically as the share of renewables increase. In parallel with developments in Turkish energy demand in the previous period, imported coal ratio in the total installed power had increased. This increase in total installed power caused the current account deficit of Turkey to widen and it increased the country's dependence on imported fossil fuels. This study has shown that the proposed complementary incentive mechanism could help the country overcome its current account deficit problem caused by the high amount of coal imports.

Increases in the subsidy rates for non-hydro renewables contribute to the growth of renewable power plants. It was found that a total of $95,700 \mathrm{MW}$ installed power addition is required until the $16^{\text {th }}$ year without the subsidy. At that time, the ratio of RES will be about $37.30 \%$ and the ratio of non-hydro RES to overall installed power is estimated as $9.45 \%$. For the investment subsidy rates of $20 \%, 40 \%$ and $50 \%$, it was observed that the ratios of non-hydro RES rose to $9.97 \%, 12.0 \%$ and $13.65 \%$, respectively.

It was found that an increase in the subsidy rates for non-hydro renewables does not affect the hydroelectric shares. The results show that hydroelectric capacity is almost stable while the renewable capacity increases. Turkey's hydroelectric potential will be fully exploited within the next $15-20$ years and a modest increase in the hydroelectric power share is anticipated in the next two decades. In view of this situation, effective and efficient utilization of RES-E is one of the most promising options for Turkey to decrease its foreign energy dependency and to mitigate GHG emissions. Turkey has amended its RESM, and inbalance cost has been inserted in FiT payments. Potential impact of the amendments on Turkey's RESM will be seen in the future. Considering the low utilization rates of the country's RES potential, policy makers should take market maturity and penetration level of RES in the power system into account for all future considerations of incentive policies. RES-E, especially electricity from wind, 
are often not balanced as it is really hard to forecast the wind speed. By considering this hurdle, implementation of this amendment may be postponed for a period of time, and different tolerance coefficients can be defined for each renewable technology to diminish the financial risk that is to be faced due to the constant tolerance co-efficient. This study has shown that proposed incentive mechanism will increase the share of RES in total installed power. The actual percentage of capital subsidy and the cost of capital subsidy to the public treasury have to be calculated, and capital subsidy incentive can be complemented with FiT, which already exists in Turkey. The implementation of this incentive scheme could be started from unlicensed electricity generation from renewable power plants. One positive development has been the introduction of incentives for rooftop and facade PV systems of up to $10 \mathrm{~kW}$ while another one is the exemption of excess generation from income tax through Renewable Energy Resources Support Mechanism (YEKDEM), which means that when the system generates more electricity than needed during the billing period, net metering customers get bill credits. These policies both lower the costs and enable smoother operation of the system by obviating the need for certain procedures. The existing 10-year subsidization period is shorter in comparison to many EU countries that tend to provide it for 15 years. Extending the "premium for use of domestic equipment" scheme, which is currently provided only to licensed plants, to the facilities of up to $10 \mathrm{~kW}$ for a period of five years would promote the use of renewable energy for self-consumption. It has been announced by the MENR that the RESM will no longer be in effect by the end of 2020. Incentives for RES should be continued. A crucial consideration that will come into play with the new incentive mechanisms is what type of energy sources they should cover and how they should be implemented based on the way resources are exploited. Incentive mechanisms adopted for rooftop solar energy systems should differ from those adopted for large-scale PV systems. Municipalities should cut down on taxes in order to promote RES. For instance, they can reduce municipal solid waste and environment tax for households or businesses that use RES. Lengthy licensing and authorization periods act as a major deterrent to RES investments. Such lengthy periods slow down project development phase and increase the Levelized Cost of Generating Electricity (LCOE) for RES in Turkey in comparison to many other countries. Hence, it is important that attempts be made to shorten these periods. Market-based emissions reduction mechanisms such as carbon tax and emissions trading should also be considered to promote RES-E deployment in Turkey.

\section{References}

[1] Yorucu V. Price modeling of imported natural gas in Turkey. J. Renewable Sustainable Energy 2016; 8:013111.

[2] MENR (Republic of Turkey Ministry of Energy and Natural Resources). Energy balance sheets (1980-2014), http://www.eigm.gov.tr/tr-TR/Denge-Tablolari/Denge-Tablolari; 2016 [accessed 29 June 2016].

[3] TurkStat (Turkish Statistical Institute). Electricity generation and shares by energy resources, http://www.tuik.gov.tr/PreTablo.do?alt_id=1029; 2016 [accessed 29 June 2016].

[4] TEİAŞ (Turkish Electricity Transmission Company). 2014 operational reports, GenerationConsumption by electricity utilities and sources, http://www.teias.gov.tr/yukdagitim/yillik_menu.htm; 2014 [accessed 25 November 2015].

[5] MENR (Republic of Turkey Ministry of Energy and Natural Resources). http://www.enerji.gov.tr/tr-TR/Sayfalar/Elektrik; 2017 [accessed 25 May 2018].

[6] TurkStat (Turkish Statistical Institute). Gross Domestic Product by Production Approach, Gross Domestic Product and GDP per capita, http://www.tuik.gov.tr/UstMenu.do?metod=temelist; 2016 [accessed 18 May 2016].

[7] TEİAŞ (Turkish Electricity Transmission Company). Turkish electrical energy generation capacity projections, http://www.teias.gov.tr/YayinRapor/apk/projeksiyon/index.htm; 2017 [accessed 12 April 2017].

[8] TEİAŞ (Turkish Electricity Transmission Company). Load dispatch department operational reports, http://www.teias.gov.tr/YukTevziRaporlari.aspx; 2015 [accessed 17 June 2015]. 
[9] OECD (The Organisation for Economic Co-operation and Development). Population (indicator), https://data.oecd.org/pop/population.htm; 2015 [accessed 29 May 2015].

[10] TurkStat (Turkish Statistical Institute). The Results of Address Based Population Registration System, 2014, http://www.tuik.gov.tr/PreHaberBultenleri.do?id=18616; 2014 [accessed 28 January 2015].

[11] BP (British Petroleum). Statistical Review of World Energy 2015, http://www.bp.com/en/global/corporate/energy-economics/statistical-review-of-worldenergy.html; 2015 [accessed 04 December 2015].

[12] Eurostat (European Commission Directorate General for Statistics). Population on 1 January, http://ec.europa.eu/eurostat/tgm/table.do?tab=table\&init=1\&language=en\&pcode=tps00001\&pl ugin=1;2015 [accessed 04 December 2015].

[13] Census (U.S. Census Bureau). U.S. and world population clock, https://www.census.gov/popclock/?intcmp=home_pop; 2015 [accessed 04 December 2015].

[14] TurkStat (Turkish Statistical Institute). Greenhouse gas emissions inventory, 2014, http://www.tuik.gov.tr/PreHaberBultenleri.do?id=21582; [accessed 18 April 2016].

[15] IPC (İstanbul Policy Center-Sabanci University). Coal report-Turkey's coal policies related to climate change, economy and health, 2016, Turkey.

[16] Ozcan M. The role of renewables in increasing Turkey's self-sufficiency in electrical energy, Renew Sust Energ Rev 2018; 82 (3):2629-2639.

[17] Bilgen S, Keleş S, Sarıkaya İ, Kaygusuz K. A perspective for potential and technology of bioenergy in Turkey: Present case and future view. Renew Sust Energ Rev 2015; 48: 228-239.

[18] Atilgan B, Azapagic A. Life cycle environmental impacts of electricity from fossil fuels in Turkey. J Clean Prod 2015; 106:555-564.

[19] Schallenberg-Rodriguez J. Renewable electricity support systems: Are feed-in systems taking the lead?. Renew Sust Energ Rev 2017; 76:1422-1439.

[20] Currier KM. Cost reduction incentives in electricity markets with overlapping regulations. The Electricity Journal 2016; 29(2) 1-6.

[21] Delarue E, Van den Bergh K. Carbon mitigation in the electric power sector under cap-and-trade and renewables policies. Energ Policy 2016; 92: 34-44.

[22] Wang H, Zheng S, Zhang Y, Zhang K. Analysis of the policy effects of down stream Feed-In Tariff on China's solar photovoltaic industry. Energ Policy 2016; 95: 479-488.

[23] IRENA (The International Renewable Energy Agency), http://www.irena.org//media/Files/IRENA/Agency/Publication/2018/Apr/IRENA_Auctions_Sub-

Saharan_Africa_2018.pdf [accessed 10 May 2018].

[24] Aquilaa G, de Oliveira Pamplona E, de Queiroz AR, Junior PR, Fonseca MN. An overview of incentive policies for the expansion of renewable energy generation in electricity power systems and the Brazilian experience. Renew Sust Energ Rev 2017; 70:1090-1098.

[25] Haghi E, Raahemifar K, Fowler M. Investigating the effect of renewable energy incentives and hydrogen storage on advantages of stakeholders in a microgrid. Energ Policy 2018;113:206222.

[26] Abdmouleh Z, Alammari RAM, Gastli A. Review of policies encouraging renewable energy integration \& best practices. Renew Sustain Energ Rev 2015; 45:249 - 262 .

[27] Baris K, Kucukali S. Availibility of renewable energy sources in Turkey: Current situation, potential, government policies and the EU perspective. Energ Policy 2012; 42: 377-391.

[28] Balat M. Security of energy supply in Turkey: Challenges and solutions. Energ Convers Manage 2010; 51(10): 1998-2011.

[29] Sirin SM, Ege A. Overcoming problems in Turkey's renewable energy policy: How can EU contribute?. Renew Sust Energ Rev 2012; 16(7):4917-4926.

[30] Aksoy N. Electricity generation from geothermal, Turkey. In: 11th National Installation Engineering Congress. http://www.mmo.org.tr/resimler/dosya_ekler/f058c634d01b96a_ek.pdf; 2013 [accessed 09 February 2016]. 
[31] Pereira S, Ferreira P, Vaz AIF. Optimization modeling to support renewables integration in power systems. Renew Sust Energ Rev 2016; 55: 316-325.

[32] Aghaei J, Akbari MA, Roosta A, Baharvandi A. Multiobjective generation expansion planning considering power system adequacy. Electr Pow Syst Res 2013; 102: 8- 19.

[33] Bagheri A, Monsef $\mathrm{H}$, Lesani $\mathrm{H}$. Integrated distribution network expansion planning incorporating distributed generation considering uncertainties, reliability, and operational conditions. Int J Elec Power 2015; 73: 56-70.

[34] Rajesh K, Bhuvanesh A, Kannan S, Thangaraj C. Least cost generation expansion planning with solar power plant using Differential Evolution algorithm. Renew Energ 2016; 85:677- 686.

[35] Yildirim M, Erkan K, Ozturk S. Power generation expansion planning with adaptive simulated annealing genetic algorithm. Int J Energ Res 2006; 30 (14):1188-1199.

[36] Hemmati R, Hooshmand RA, Khodabakhshian A. Reliability constrained generation expansion planning with consideration of wind farms uncertainties in deregulated electricity market. Energ Convers Manage 2013;76:517-526.

[37] Murugan P, Kannan S, Baskar S. NSGA-II algorithm for multi-objective generation expansion planning problem. Electr Pow Syst Res 2009; 79: 622-628.

[38] Fagiani R, Barqui'n J, Hakvoort R. Risk-based assessment of the cost-efficiency and the effectivity of renewable energy support schemes: Certificate markets versus feed-in tariffs. Energ Policy 2013; 55: 648-661.

[39] Ritzenhofen I, Birge JR, Spinler S. The structural impact of renewable portfolio standards and feed-in tariffs on electricity markets. Eur J Oper Res 2016; 255: 224-242.

[40] Frondel M, Ritter N, Schmidt CM, Vance C. Economic impacts from the promotion of renewable energy technologies: The German experience. Energ Policy 2010; 38: 4048-4056.

[41] Butler L, Neuhoff K. Comparison of feed-in tariff, quota and auction mechanisms to support wind power development. Renew Energ 2008; 33:1854-1867.

[42] Haas R, Panzer C, Resch G, Ragwitz M, Reece G, Held A. A historical review of promotion strategies for electricity from renewable energy sources in EU countries. Renew Sust Energ Rev 2011;15:1003-1034.

[43] PwC (PricewaterhouseCoopers) International Limited Turkey. Turkey's renewable energy sector from a global perspective. 2012, Turkey.

[44] REN21 (Renewable Energy Policy Network fort he 21st Century). Renewables 2016 global status report. ISBN 978-3-9818107-0-7, 2016, France.

[45] OECD/IEA (International Energy Agency). Deploying renewables 2011, 2011, France.

[46] Hsu CW, Ho SP. Assessing feed-in tariffs on wind power installation and industry development in Taiwan. Renew Sust Energ Rev 2016; 58: 548-557.

[47] Pyrgou A, Kylili A, Fokaides PA. The future of the Feed-in Tariff (FiT) scheme in Europe: The case of photovoltaics. Energ Policy 2016; 95:94-102.

[48] Huenteler J, Schmidt TS, Kanie N. Japan's post-Fukushima challenge - implications from the German experience on renewable energy policy. Energ Policy 2012; 45: 6-11.

[49] Pegels A, Lütkenhorst W. Is Germany's energy transition a case of successful green industrial policy? Contrasting wind and solar PV. Energ Policy 2014; 74:522-534.

[50] Strunz S. The German energy transition as a regime shift. Ecol Econ 2014; 100:150-158.

[51] Guidolin M, Guseo R. The German energy transition: Modeling competition and substitution between nuclear power and Renewable Energy Technologies. Renew Sust Energ Rev 2016; 60:1498-1504.

[52] Polo AL, Haas R. An international overview of promotion policies for grid-connected photovoltaic systems.Prog. Photovolt: Res. Appl. 2014; 22(2):248-273.

[53] Aquila G, Pamplona EdO, Queiroz AR, Junior PR, Fonsecaa MN. An overview of incentive policies for the expansion of renewable energy generation in electricity power systems and the Brazilian experience. Renew Sust Energ Rev 2017; 70:1090-1098.

[54] Pablo-Romero MdP. Solar Energy: Incentives to Promote PV in EU27. AIMS Energy 2013;1:2847. 
[55] IBRD (International Bank for Reconstruction and Development / The World Bank). The Design and Sustainability of Renewable Energy Incentives An Economic Analysis. 2015, USA.

[56] Law no 6094 on Making of Amendment on the Law of Renewable Energy Resources for the Generation of Electrical Energy, Official Gazette. 27809 (2011).

[57] Law no 4706 on making amendments to the law on the valuation of immovable properties belonging to the treasury and value added tax, Official Gazette. 24466 (2001).

[58] Law no 6446 on Electricity Market law, Official Gazette. 28603 (2013).

[59] Electricity market Licensing Regulation, Official Gazette. 24836 (2002).

[60] Regulation on the amendment of the regulation on the documentation and support of renewable energy sources, Official Gazette. 29698 (2016).

[61] Yildirim M, Erkan K. Determination of acceptable operating cost level of nuclear energy for Turkey's power system. Energy 2007;32 (2):128-136.

[62] Sivanandam SN, Deepa SN. Introduction to Genetic Algorithms. Berlin:Springer; 2008.

[63] Gavela P, Rueda JL, Vargas A, Erlich I. Performance comparison of heuristic optimization methods for optimal dynamic transmission expansion planning. Int. Trans. Electr. Energ. Syst. 2014; 24(10):1450-1472.

[64] Sadeghi H, Rashidinejad M, Abdollahi A. A comprehensive sequential review study through the generation expansion planning. Renew Sust Energ Rev 2017; 67:1369-1394.

[65] Hassan AA, Fahmy FH, Nafeh AESA, Abu-elmagd MA. Hybrid genetic multi objective/fuzzy algorithm for optimal sizing and allocation of renewable DG systems. Int. Trans. Electr. Energ. Syst. 2016; 26(12):2588-2617.

[66] Ciornei I, Kyriakides E. Recent methodologies and approaches for the economic dispatch of generation in power systems. Int. Trans. Elect. Energ. Syst. 2013; 23(7):1002-1027.

[67] Park JB, Park YM, Won JR, Lee KY. An improved genetic algorithm for generation expansion planning. IEEE T Power Syst 2000;15: 916-922.

[68] Tuncer A, Yildirim M. Dynamic path planning of mobile robots with improved genetic algorithm. Comput Electr Eng 2012; 38:1564-1572.

[69] Ozcan M. Effects of renewable energy resources in long-term generation expansion planning of Turkey, Ph.D. Thesis, Kocaeli University, Institute of Natural and Applied Science, 2013, Kocaeli, Turkey.

[70] Ozcan M, Ozturk S, Yildirim M. Turkey's long-term generation expansion planning with the inclusion of renewable-energy sources. Comput Electr Eng 2014; 40(7), 2050-2061.

[71] TEİAŞ (Turkey General Directorate of Electric Transmission Joint Stock Company), 10-year (2011-2020) generation capacity projection of Turkey's electric energy, 2011. 